\title{
Bioaccessible peptides released by in vitro gastrointestinal digestion of fermented goat milks
}

Article

Accepted Version

Moreno-Montoro, M., Jauregi, P., Navarro-Alarcón, M., OlallaHerrera, M., Giménez-Martínez, R., Amigo, L. and Miralles, B. (2018) Bioaccessible peptides released by in vitro gastrointestinal digestion of fermented goat milks. Analytical and Bioanalytical Chemistry, 410 (15). pp. 3597-3606. ISSN 1618-2650 doi: https://doi.org/10.1007/s00216-018-0983-0 Available at https://centaur.reading.ac.uk/76124/

It is advisable to refer to the publisher's version if you intend to cite from the work. See Guidance on citing.

To link to this article DOI: http://dx.doi.org/10.1007/s00216-018-0983-0

Publisher: Springer

All outputs in CentAUR are protected by Intellectual Property Rights law, including copyright law. Copyright and IPR is retained by the creators or other copyright holders. Terms and conditions for use of this material are defined in the End User Agreement. 


\section{CentAUR}

Central Archive at the University of Reading

Reading's research outputs online 
Bioaccessible peptides released by in vitro gastrointestinal digestion of fermented goat milks

Miriam Moreno-Montoro', Paula Jauregi², Miguel Navarro-Alarcón ${ }^{1}$, Manuel Olalla-Herrera $^{1}$, Rafael Giménez-Martínez ${ }^{1}$, Lourdes Amigo² ${ }^{2}$, Beatriz Miralles ${ }^{2}$

${ }^{1}$ Departament of Nutrition and Food Science, Faculty of Pharmacy, University of Granada, Campus de Cartuja s/n, 18071 Granada, Spain

${ }^{2}$ Department of Food and Nutritional Sciences, The University of Reading, Whiteknights, PO Box 226, Reading, RG6 6AP, UK

${ }^{3}$ Department of Bioactivity and Food Analysis. Institute of Food Science Research (CIAL, CSIC-UAM,), Nicolas Cabrera 9, 28049 Madrid, Spain

Corresponding author: Beatriz Miralles

beatriz.miralles@ csic.es

Tel.: +34910017932

Orcid Number: 0000-0003-4544-9074 


\section{Abstract}

In this study, ultrafiltered goat milks fermented with the classical starter bacteria Lactobacillus delbrueckii subsp. bulgaricus and Streptococcus salivarus subsp. thermophilus or with the classical starter plus the Lactobacillus plantarum $\mathrm{C} 4$ probiotic strain were analyzed using ultra-high performance liquid chromatography-quadrupoletime-of-flight tandem mass spectrometry (UPLC-Q-TOF-MS/MS) and/or liquid chromatography-ion trap (LC-IT-MS/MS). Partial overlapping of the identified sequences with regard to fermentation culture was observed. Evaluation of the cleavage specificity suggested a lower proteolytic activity of the probiotic strain. Some of the potentially identified peptides had been previously reported as angiotensin converting enzyme (ACE)-inhibitory, antioxidant and antibacterial and might account for the in vitro activity previously reported for these fermented milks. Simulated digestion of the products was conducted in presence of a dialysis membrane to retrieve the bioaccessible peptide fraction. Some sequences with reported physiological activity resisted digestion but were found in the non-dialyzable fraction. However, non-previously detected sequences such as the antioxidant $\alpha_{\mathrm{s} 1}$-casein ${ }^{144} \mathrm{YFYPQL}^{149}$, the antihypertensive $\alpha_{\mathrm{s} 2}$ casein ${ }^{90}{ }^{Y Q K F P Q Y}{ }^{96}$ and the antibacterial $\alpha_{\mathrm{s} 2}$-casein ${ }^{165} \mathrm{LKKISQ}^{170}$ were found in the dialyzable fraction of both fermented milks. Moreover, in the fermented milk including the probiotic strain, the k-casein dipeptidyl peptidase IV inhibitor (DPP-IV) ${ }^{51}$ INNQFLPYPY ${ }^{60}$ as well as additional ACE-inhibitory or antioxidant sequences could be identified. With the aim to anticipate further biological outcomes, quantitative structure activity relationship (QSAR) analysis was applied to the bioaccessible fragments and led to propose potential ACE inhibitory sequences. 
Keywords: Fermented goat's milk; Bioaccessible peptides; Tandem mass spectrometry; Gastrointestinal digestion; Peptidomics 


\section{Introduction}

Fermented milk products have a long history of being beneficial to human health. The physiological effects are often attributed to the action of probiotic microflora in the product. In milk fermentation the involved metabolites contribute to confer chemical, biochemical and nutritional attributes [1]. The proteolytic system of lactic-acid bacteria comprises extracellular cell-wall bound proteinases that initiate the degradation of milk proteins into oligopeptides, peptide transporters that take up the peptides into the cell, and various intracellular peptidases that degrade the peptides into shorter peptides and amino acids [2]. This can lead to the release of peptides with bioactive properties from fermented dairy products [3]. The proteolytic activity is influenced by the type of dairy product, the technology adopted and, specially, the bacterial strain [4]. In some cases, a combination of selected yeasts and lactic acid bacteria is used with the aim to generate peptides with known health benefits. Thus, a screening with lactic acid bacteria lead to select a mixed starter containing Streptococcus thermophilus and different Lactobacillus strains (casei, helveticus, plantarum) to produce goats' milk with $\gamma$-aminobutyric acid (GABA) and angiotensin-I converting enzyme (ACE)-inhibitory peptides [5]. Caprine milk fermentation products, such as kefir, have been the source of ACE inhibitory peptides [6, 7]. We have recently demonstrated that fermentation of ultrafiltered goat's milk with lactic acid bacteria including Lactobacillus plantarum $\mathrm{C} 4$, a strain with demonstrated probiotic activity in terms of in vitro intestinal microbiota modulation [8], results in the development several biological activities [9]. In this regard, the proteolytic nature and ability to generate bioactive peptides of this strain remained to be investigated.

There is a general agreement that caprine milk is more easily digested than bovine milk, a major factor affecting digestibility being the size of the lipid globules [10]. Bovine and caprine milk differ in protein composition and the lower content of $\alpha_{\mathrm{s} 1}$-casein in 
goat's milk has been associated with its lower allergenicity. Moreover, the content in this protein is related to milk coagulation properties, which influence protein digestibility. Studies on the peptides released after the simulated gastrointestinal digestion of goat milk proteins have shown the release of ACE [11], [12] and dipeptidyl peptidase IV (DPP-IV) inhibitory sequences [13] as well as antibacterial [14] and antioxidant peptides [15]. Interestingly, in fermented goat's milk products, such as cheese, some peptides with reported physiological activities have shown resistance to in vitro gastrointestinal digestion, such as the antihypertensive peptide $\beta$-casein, ${ }^{133}$ LHLPLP $^{138}$ [16].

The objective of this research was to identify the peptides produced by Lactobacillus delbrueckii subsp. bulgaricus and Streptococcus thermophilus with or without co-culture with the probiotic strain Lactobacillus plantarum $\mathrm{C} 4$ during the manufacturing of fermented goat milks. In vitro gastrointestinal digestion in combination with dialysis was conducted to evaluate the resistance and bioaccesibility of the released protein fragments. Since the assayed fermented milks had previously shown antioxidant, ACE-inhibitory and antimicrobial activity, comparison of the resistant peptides sequences with those reported in the literature and in combination of computer-assisted prediction for ACE inhibition led to the identification of most bioactive peptide sequences in the fermented goat milks.

\section{Materials and methods}

\section{Chemicals and samples}

Raw goat milk samples from Murciano-Granadina breed were collected from a farm in the region of Granada (Spain). They were skimmed by centrifugation and concentrated by ultrafiltration through a $50 \mathrm{kDa}$ membrane (Vivaflow 2000, Sartorius Stedin Biotech, Madrid, Spain). Fermentation was conducted with (i) the classical starter bacteria 
Lactobacillus delbrueckii subsp. bulgaricus and Streptococcus salivarius subsp. thermophile ( $\mathrm{St}$ ) and (ii) $\mathrm{St}+$ the probiotic strain Lactobacillus plantarum $\mathrm{C} 4$ [8] (St+ LP). Enzymes and bile salts were purchased from Sigma Chemical Co (St Louis, MO, USA), porcine pepsin (P-7000), porcine pancreatin (P-1500) and porcine bile extract (B8631). All other reagents such as $\mathrm{HCl}$, ammonia, $\mathrm{NaHCO}_{3}$, formic acid, acetonitrile, were purchased from Sigma Chemical.

\section{Isolation of peptide fractions}

Fermented goat milk samples were isolated based on the method developed by [17] with some modifications. In the first step, samples were centrifuged at 3,000 $\mathrm{g}$ for $30 \mathrm{~min}$ at 4 ${ }^{\circ} \mathrm{C}$ (Sigma 2-16PK, Sartorius, Goettingen, Germany). The precipitate was discarded and the supernatant was adjusted to $\mathrm{pH} 2.0$ by addition of $\mathrm{HCl}$. In the second step, the acidified supernatant was filtered through a $30 \mathrm{kDa}$ cut off ultrafiltration membrane (Vivaspin20, Sartorius) and $100 \mathrm{ml}$ of the filtrate was applied to a Dowex $50 \mathrm{WX} 2$ cation exchange column (2.6 x 10 cm, H+-form, 200-400 mesh, Serva, Heidelberg, Germany). After washing with $60 \mathrm{ml}$ of Milli-Q water, peptides were eluted with $200 \mathrm{ml}$ of $2 \mathrm{M}$ aqueous ammonia. Ammonia was firstly evaporated in vacuo and then samples were freeze dried. This procedure was carried out by duplicate.

\section{In vitro gastrointestinal digestion of the fermented goat milk samples}

Fermented goat milk samples were subjected to in vitro gastrointestinal digestion in duplicate as described by [18]. Briefly, $20 \mathrm{~g}$ of each fermented milk were homogenized with $60 \mathrm{ml}$ of Milli-Q water and subjected to gastric digestion with pepsin and duodenal digestion with pancreatin/bile solution. To stop intestinal digestion, samples were immersed in a water-bath at $100{ }^{\circ} \mathrm{C}$ for $5 \mathrm{~min}$. The digests were centrifuged at $3,500 \mathrm{~g}$ for 
1 hour at $4{ }^{\circ} \mathrm{C}$ and the supernatants, the soluble fraction, were freeze dried and kept until the analysis. The dialysis assay was carried out according to [18] to identify the potential bioaccessible peptides. It comprised a gastric step followed by an intestinal step where dialysis was included (dialysis bag: molecular weight 12-14 kDa; Visking 45 mm x 27 $\mathrm{mm}$, Medicell International, London, UK). Dialysis tubing, containing $25 \mathrm{ml}$ of bidistilled deionized water and an amount of $\mathrm{NaHCO}_{3}$ equivalent to titratable acidity measured previously, were placed in the flasks together with $20 \mathrm{~g}$ aliquots of the pepsin digest and incubated in the shaken bath at $37^{\circ} \mathrm{C}$ for $30 \mathrm{~min}$. An amount of freshly prepared pancreatin-bile extract mixture $(0.001 \mathrm{~g}$ pancreatin and $0.006 \mathrm{~g}$ bile sals/samples) was added to the flask and the incubation continued up to $2 \mathrm{~h}$. Dialyzable and non-dialyzable fractions were weighted, freeze dried and stored until the assay.

\section{Total soluble protein content}

The total protein content of the samples was determined based on the bicinchoninic acid assay according to the instructions of Thermo Scientific ${ }^{\mathrm{TM}}$ Pierce $^{\mathrm{TM}}$ BCA $^{\mathrm{TM}}$ Protein Assay kit, in a 96 well plate using a FLUOStar Omega microplate reader (BMG Labtech, Germany). Serial dilutions with bovine serum albumin (provided with the kit) were used as standard. Results were expressed as $\mathrm{mg} / \mathrm{mL}$.

\section{Analysis by on-line reverse-phase high performance liquid chromatography tandem mass spectrometry (LC-MS/MS)}

Before injection, fermented goat milk samples after ion exchange and digested samples were dissolved in water with formic acid $(0.1 \%)$ at $2 \mathrm{mg} / \mathrm{mL}$ protein concentration and centrifuged at $10,000 \mathrm{~g}$ to precipitate all impurities. If turbidity was shown, also a filtration 
step through $0.45 \mu \mathrm{m} \mu \mathrm{m}$ size pore filters (Millex ${ }^{\circledR}-\mathrm{GS}$, Merck Millipore Ltd., Cork, Ireland) was carried out.

Chromatographic analysis of the samples was performed with an Acquity UPLC ${ }^{\circledR}$ system (Waters Technologies, Cerdanyola del Vallès, Spain) with an Acquity UPLC BEH 130 column, a C18 column $100 \mathrm{~mm}$ of length, $2.1 \mathrm{~mm}$ of internal diameter, $1.7 \mu \mathrm{m}$ of particle size and $130 \AA$ of pore diameter (Waters Technologies, Cerdanyola del Vallès, Spain). The UPLC system was connected online to a quadrupole-time of flight MS/MS detector, equipped with an electrospray ionization source (Bruker Daltonik, Bremen, Germany). Solvent A was water with $0.1 \%$ formic acid and solvent B was acetonitrile with $0.1 \%$ formic acid and the flow used was $0.2 \mathrm{~mL} / \mathrm{min}$. The peptide fractions were eluted with an isocratic gradient after 1 min of pure solvent A, up to $35 \%$ B within 28 min, then in 2 min $70 \%$ of solvent B was reached and maintained during 2.5 minutes. The injection volume was $15 \mu \mathrm{L}$ and the absorbance was monitored at $214 \mathrm{~nm}$. The nebulizer pressure was set at 2 bar, the temperature of the source at $180{ }^{\circ} \mathrm{C}$ and the capillary voltage at $4.5 \mathrm{kV}$ Spectra were recorded over the mass/charge $(\mathrm{m} / \mathrm{z})$ range 50 1500 and 3 spectra were averaged in the MS analyses. The signal threshold to perform auto MS (n) analyses was 5,000 counts and three precursor ions were isolated within a range of $100-1500 \mathrm{~m} / \mathrm{z}$ and fragmented with a voltage ramp depending of the isolation mass of the precursor ion, from 20 to $70 \mathrm{eV}$.

Alternatively, the analyses were performed on an Agilent 1100 HPLC system (Agilent Technologies, Waldbronn, Germany) followed by on-line MS/MS analysis on an ion trap instrument (Esquire 3000, Bruker Daltonik GmbH, Bremen, Germany) as previously described [16]. Chromatographic separations were performed with a Mediterranea Sea18 $150 \mathrm{~mm} \times 2.1 \mathrm{~mm}$ column (Teknokroma, Barcelona, Spain) Samples were injected at a protein concentration of $1 \mathrm{mg} / \mathrm{mL}$, the flow rate was 0.2 
$\mathrm{mL} / \mathrm{min}$ and the injection volume was $50 \mu \mathrm{L}$. Peptides were eluted with a linear gradient from $10 \%$ to $55 \%$ of solvent B (acetonitrile: formic acid $0.1 \%$ ) and $45 \%$ solvent A (water: formic acid 0.1\%) in 95 min. Data Analysis (version 4.0; Bruker Daltoniks) was used to process and transform spectra. Data were processed with Data Analysis TM (version 4.0, Bruker Daltonik, Bremen, Germany). The $\mathrm{m} / \mathrm{z}$ spectral data were processed with Biotools (Version 3.2, Bruker Daltonik, Bremen, Germany) where the deconvoluted mass spectra were matched against a homemade database with the main goat milk proteins ( $\alpha_{\mathrm{s} 1}$-casein, $\alpha_{\mathrm{s} 2}$-casein, $\beta$-casein, $\kappa$-casein, $\alpha$-lactoalbumin and $\beta$-lactoglobulin) sequences retrieved from the UniprotKB database (uniprot.org). Peptide sequencing was performed by MASCOT (matrixscience.com) with error tolerances $0.1 \%$ for precursor masses and 0.5 Da for fragment masses. Only individual scores indicating identity or extensive homology were used. Besides, he matched MS/MS spectra were interpreted by using BioTools version 3.2 (Bruker).

\section{Peptide profile analysis}

$\begin{array}{lllll}\text { Venn's diagrams } & \text { were } & \text { executed } & \text { with } & \text { Venny }\end{array}$ (http://bioinfogp.cnb.csic.es/tools/venny/index.html). The Enzyme Predictor tool [19] was used to analyze protein cleavages in the peptides. The identified peptides were searched against the BIOPEP bioactive peptide database [20]. The AHT pin in silico platform (http://crdd.osdd.net/raghava/ahtpin/\#) [21] was used in the variable length mode, amino acid composition model, and the SVM threshold was set to 0.9.

\section{Results and discussion}

Peptide profile analysis 
The fermented milks were submitted to cation exchange at $\mathrm{pH} 2$ followed by elution with ammonia in order to recover the whole peptide fraction. Fermented milk with St showed a higher protein concentration $(0.013 \pm 0.003)$ than $\mathrm{St}+\mathrm{LP}(0.009 \pm 0.002)$. These values might account for the fermentation differences with more protein coagulation and less soluble protein/peptides in the case of $\mathrm{St}+\mathrm{LP}$, as previously observed [9]. A combination of two complementary LC-MS/MS settings to cover a wide range of sequence lengths permitted the potential identification of a total of 232 different peptides in St and St+LP fermented goat milks. From these, $46 \%$ corresponded to $\beta$-casein, $24 \%$ to $\alpha_{\mathrm{s} 2}$-casein, 18

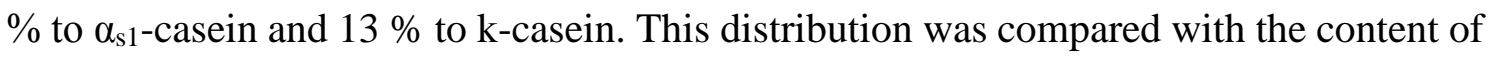
the different caseins in goat's milk. In contrast to cow's milk, where the most abundant protein is $\alpha_{\mathrm{s} 1}$-casein (38\%) followed by $\beta$-casein (35\%), k- and $\alpha_{\mathrm{s} 2}$-casein (10-11\%), goat's milk displays a higher proportion of $\beta$-casein (55\%) and $\alpha_{\mathrm{s} 2}$-casein (25\%) and a lower amount of $\alpha_{\mathrm{s} 1}$-casein (5\%) [22]. The resulting peptides are in accordance with this protein composition, which indicates a balanced proteolysis of the main caseins. Peptides from $\beta$-casein covered almost completely the sequence, but the highest number of peptides corresponded to the (180-207) region (Electronic supplementary material Table S1). Miclo et al. [23] reported this region as more accessible to the cell envelope protease of $S$. thermophilus. In contrast, the (15-40) region of $\beta$-casein was poorly represented in terms of potentially identified peptide sequences. This region comprises four phosphorylated serines and it is known that the ionization of these sequences in a complex mixture is difficult. However, the caseinophosphopeptides from $\beta$-casein ${ }^{15} \mathrm{SpSpSpEESITHINK}{ }^{28}$, and ${ }^{29}$ KIEKFQSpEEQQQTED ${ }^{43}$ could be potentially identified in some samples.

It has to be highlighted that peptides from $\alpha_{\mathrm{s} 1}$-casein were relatively abundant with regard to its low content in caprine milk (Electronic supplementary material Table S2). 
The $\alpha_{\mathrm{s} 1}$-casein structure is composed of four parts: (1) hydrophilic region (1-12), (2) hydrophobic region (13-40), (3) hydrophilic region (41-99), (4) hydrophobic region (100199) [24]. In the present study almost all peptides were released from the hydrophobic regions, the most hydrolyzed region being that corresponding to the $\mathrm{N}$-terminal hydrophobic region (22-40). Miclo et al [23] noted that the S. thermophilus cleavages gave rise to most peptides within the first 40 amino acid residues while the (41-99) and (152-159) regions appeared more resistant to hydrolysis and a low number of cleavage sites were observed. Accessibility to substrate was considered the determinant parameter in the protein susceptibility to hydrolysis rather than hydrophobicity. Besides, the missing peptides could derive from the phosphorylation of several residues, which impairs peptide ionization. Thus, the observed results show the contribution of different factors. No peptides from whey proteins, $\alpha$-lactalbumin and $\beta$-lactoglobulin could be identified, which could be due to the low susceptibility of these compact proteins to the proteolytic action of lactic acid bacteria.

\section{Enzymatic cleavages analysis}

By the use of a sequence discrimination tool, a distinction in the generated peptides with regard to fermentation culture was revealed (Figure 1). More than $40 \%$ of potentially identified peptides were constant in both fermented milks, which is not surprising due to the presence of the classical starter in both. However, the addition of the probiotic strain, St+LP, showed an influence on the resulting protein cleavage, with 69 exclusive sequences in this case, a similar number to the 62 exclusive fragments generated in milk fermented by the classical starter, St. In order to evaluate the hypothesis of a differential enzyme activity between cultures, a computer-assisted study of enzyme specificity was performed on the identified sequences with the EnzymePredictor program [19]. Table 1 
shows the preferential enzyme cleavage rules determined for peptide sequences arisen by the action of St and St+LP. In the two best ranked enzyme specificities, no relevant differences could be found. However, the succeeding specificities were different between the fermented milks in terms of significance and a higher weight was given to the cleavage giving rise to $\mathrm{C}$-terminal lysine or arginine in the case of St+LP. This cleavage specificity could be ascribed to plasmin, an endogenous enzyme in milk, responsible for the hydrolysis of $\alpha$ - and $\beta$-caseins. The stage of lactation affects plasmin activity and, with regard to other species, the effect in dairy goats is more pronounced since, having a seasonal breeding, they progress through lactation in a synchronous manner [25]. The higher importance of plasmin in the peptides generated by the fermented milk with St+LP could be attributed to a lower proteolytic power of the probiotic strain. This would explain this product to retain the protein cleavages present before fermentation. Therefore, although no particular enzyme could be distinctively predicted, the pattern indicated a lower proteolytic activity in St+LP milk in comparison to the classical starter bacteria, St, at least at the studied fermentation time.

\section{Peptide bioactivity analysis}

These fermented milks have previously shown ACE-inhibition, antibacterial activity against E. coli, and antioxidant capacity using different in vitro methods [9]. Peptide sequences with such reported activities or very close precursors could be found, not only with goat's milk origin but from bovine or ovine milk, due to the high sequence homology between the caseins from these dairy species. Thus, the $\beta$-casein ${ }^{58}$ LVYPFTGPIPN $^{68}$, which has shown antihypertensive activity in spontaneously hypertensive rats [26] was found in samples fermented with the classical starter, St. The $\beta$-casein ${ }^{195}$ VLGPVRGPFPI $^{205}$, greatly overlaps with the antihypertensive fragment generated by 
E. faecalis on bovine milk, ${ }^{197}$ VLGPVRGPFP ${ }^{206}$. Other potentiallyidentified peptides from $\beta$-casein were $\mathrm{f}(78-93), \mathrm{f}(134-139), \mathrm{f}(166-175)$, precursors of the antihypertensive sequences ${ }^{80} \mathrm{TPVVVPPKLPQ}{ }^{90},{ }^{134} \mathrm{HLPLP}^{138}$, and ${ }^{169} \mathrm{KVLPVPQ}^{175}$, respectively [27], [26], [28]. Several peptides from the C-terminal $\beta$-casein region covered cow's milk sequence ${ }^{199}$ VRGPFPIIV ${ }^{207}$, with reported antihypertensive activity [29]. Despite this, and due to the different penultimate residue at the C-terminal sequence, leucine in goat's milk, the activity of identified peptides would probably be different to the reported by others. Those differences between goat and cow protein sequences were previously denoted as the probable reason for the difference in ACE inhibitory activity between ${ }^{200}$ GPFPILV $^{206} \quad($ IC50=424 $\mu \mathrm{M})$ derived from caprine $\beta$-casein and ${ }^{191}{ }^{2 L Y Q Q P V L G P V R G P F P I I V ~}{ }^{209}$ (IC50=22 $\mu \mathrm{M}$ ) released from bovine $\beta$-casein by hydrolysis with Lactobacillus helveticus CP790 proteinase [6].

Regarding other biological activities, the $\beta$-casein peptide ${ }^{191}$ YQEPVLGPVRGPFPI ${ }^{205}$, corresponds to casecidin 15, an antimicrobial sequence with minimal inhibition concentration against E. coli DPC6053 of $0.4 \mathrm{mg} \mathrm{ml}^{-1}$ [30]. On the other hand, the $\beta$-casein antioxidant peptide ${ }^{59}$ VYPFTGPIPN $^{68}$ [31] was also potentially identified. Most of these physiologically active sequences were found in the fermented milks with both cultures (see Electronic supplementary material), which supports the previously antioxidant, ACE-inhibitory and antimicrobial activities observed.

\section{Peptide resistance to simulated digestion}

Simulated digestion of fermented milks was conducted with a dialysis device intended to recover the bioaccessible fraction of peptides resistant to the digestion conditions. The UV-UPLC chromatographic profile of the dialyzable and non-dialyzable fractions of a digested St milk sample has been evaluated (Figure 2). The chromatographic profile does 
not greatly differ between fractions although an additional peak at 30 min can be observed in the non-dialyzable fraction while other peaks vary in intensity.

In the LC-MS/MS analysis a total number of 151 different peptides could be potentially identified when taken together the dialyzed and non-dialyzed fractions. From them, 72 peptides were common to St and St+ LP milks (Figure 3). The overlapping of released peptides between fermentation cultures was slightly higher after digestion (47.7 vs $43.5 \%$ ) but, still, differences in the fermented milks could be evidenced in the peptide profile, which supports the influence of the starter on the resulting digestome. The lower number of different peptides after digestion is attributed to the increase in sequence homology, as it has been previously observed [16]. Table 4 shows, from the common identified peptides, those present in the dialyzed fraction after in vitro digestion, because this would constitute the bioaccessible fraction. In order to know if physicochemical parameters of the sequences might determine their accumulation in the dialyzed fraction, an analysis of hydropathicity and charge of sequences was performed. The first parameter gives information about the structure of the peptide based on its hydrophobicity and hydrophilicity [32]. Notable dispersion within values was observed, with broad ranges observed for hydropathicity $(-2.45$ and 1.48$)$ and charge $(-2$ to +2$)$. Therefore, the peptides recovered in the dialyzed fraction could not be associated to particular features with regard to these physicochemical parameters.

On the other hand, sequence descriptors permit to anticipate the biological activity of peptides when the rationale behind their effect is defined in relation to the amino acid chain. These sequences have been analyzed with a QSAR tool for ACE inhibition Kumar [21]. The classification model assigns the peptides to the category of potentially active (AHT) or inactive (non-AHT) in accordance to the specificity selected (Table 4). In this case the SVM score threshold was selected to provide high specificity. Positive 
descriptions were assigned to some sequences, with relatively high scores (over 1.7) in the case of eight sequences derived from $\beta$ - and $\alpha_{\mathrm{s} 1}$-casein. Some of these sequences had been reported as ACE inhibitors such as $\alpha_{\mathrm{s} 1}$-casein ${ }^{151}{ }^{\text {DAYPSGAW }}{ }^{164}$ [33]. The identified $\beta$-casein $\mathrm{f}(81-89)$ displays an ample overlapping with $\beta$-casein ACE-inhibitor ${ }^{80}$ TPVVVPPFLQP $^{90}$ [27]. On the contrary, lower ranked sequences have also been described as ACE inhibitors, i. e. $\alpha_{\mathrm{s} 2}$-casein ${ }^{165} \mathrm{LKKISQ}^{170}$ [34] and $\beta$-lactoglobulin ${ }^{33}$ DAQSAPLRV $^{41}[35]$.

The ACE-inhibition mechanism of action of peptides is not well known yet. In general, ACE inhibitory peptides usually contain between 2-12 amino acids [36]. Despite their activity has been linked to the C-terminal region composition and sometimes the $\mathrm{N}$ terminal region influences the ACE inhibitory activity of peptides with less than six amino acid residues, the reason for the activity of higher molecular weight peptides is still unknown [37]. The presence in C-terminal position of aliphatic, aromatic or branched chain amino acids as tryptophan, tyrosine, phenylalanine, leucine, as well as proline has been considered an important feature [38],[39]. Moreover, the presence of basic amino acids such as lysine or arginine, at the C-terminal or ultimate chain position also influences this activity [40]. On the other hand, some highly ranked sequences in Table 4 have not been reported as ACE inhibitors although they fulfill these features and would merit further studies. This would be the case of sequences $\alpha_{\text {s2 } 2 \text {-casein }}$ ${ }^{97}$ LQYPYQGPIVL $^{107}$, and $\beta$-casein ${ }^{90} \mathrm{PEIMGVPK}^{97}$, and ${ }^{157} \mathrm{FPPQSVL}^{163}$.

Regarding the antioxidant activity, the presence of the hydrophobic amino acid residues valine or leucine at the $\mathrm{N}$-terminus and proline, histidine, or tyrosine in the amino acid sequence are related with antioxidant peptides, and the presence and position of tryptophan, tyrosine and methionine are thought to be responsible for the antioxidant activity [41]. In addition, casein derived peptides with glutamic and aspartic acids have 
been reported as able to inhibit lipid peroxidation and acid and basic amino acids played an important role in metal chelation [17]. Antibacterial activity, in turn, has been related with the peptide charge but the influence of additional physicochemical and structural properties in the mechanism of action remains to be elucidated [42].

Table 5 shows the peptides potentially found in the dialyzable fraction of St and St+LP fermented milks with reported physiological effects. Peptides with ACE inhibitory, antihypertensive, antioxidative, antibacterial, and DPP-IV inhibitory activities from the main caprine caseins and $\beta$-lactoglobulin could be found. In three cases, the determined sequence was comprised in a slightly longer active sequence. Some of these sequences are novel products from goat's milk simulated digestion, such as k-casein ${ }^{51}$ INNQFLPYPY ${ }^{60}$. The presence of this fragment in milk fermented with the probiotic culture Lactobacillus plantarum $\mathrm{C} 4$ after digestion deserves attention with regard to its potential DPP-IV inhibitory activity, related to the increase of lifetime of incretins. Some peptides with reported biologically activity observed before digestion were found in the non-dialyzable fractions, i. e. the antihypertensive $\beta$-casein ${ }^{58}$ LVYPFTGPIPN $^{68}$ or the antimicrobial $\beta$-casein ${ }^{191}$ YQEPVLGPVRGPFPI ${ }^{205}$. The dialysis might be considered an approximation to the physiological conditions of the intestinal barrier. However, the ability of the identified peptides to interact with receptors on the intestinal epithelium or to cross the mucosal barrier to exert a systemic effect should be studied to consider them as active compounds.

\section{Conclusions}

Many peptide fragments were potentially identified in the fermented milks with both cultures with a distribution according to the abundance of the parent proteins in goat's milk. Certain specificity could be assigned with regard to the different fermentation 
cultures with an apparently lower proteolytic activity of the probiotic strain based on the specific cleavages in the resulting peptides. The ACE-inhibitory, antioxidant and antibacterial activities previously determined in both fermented products might be attributed to the presence of peptides with these physiological effects. After simulated digestion, some of the active sequences remained but were found in the non-dialyzable fraction. More importantly, digestion gave rise to new active sequences that were able to cross the dialysis membrane. This merits further studies on their interactions with the intestinal mucosa to assess their potential in exerting the physiological effects. These peptides have been previously described as antihypertensive, antibacterial, antioxidative or DPP-IV inhibitors. Moreover, the application of QSAR analysis to the dialyzed peptide fragments after digestion allowed to designate new sequences that are candidates to be bioaccessible ACE inhibitors.

\section{Acknowledgements}

This work has received financial support from project AGL2015-66886-R from the Spanish Ministry of Economy and Competitiveness (MINECO). The authors would like to thank to Spanish Ministry of Education for a predoctoral scholarship awarded to M. Moreno-Montoro.

Conflict of interest. The authors declare that they have no conflict of interest. 


\section{Figure captions}

Figure 1. Venn diagrams of the peptide sequences potentially identified in the goat milk fermented with the classical starter, St, and the classical starter plus Lactobacillus plantarum $\mathrm{C} 4$, $\mathrm{St}+\mathrm{LP}$

Figure 2. UV-chromatographic profile of a) dialyzable fraction b) non-dialyzable fraction of goat's milk fermented with the classical starter, St.

Figure 3. Venn diagrams of the peptide sequences potentially identified in the goat milk fermented with the classical starter, St, and the classical starter plus Lactobacillus plantarum $\mathrm{C} 4$, St+LP after in vitro gastrointestinal digestion. 
Table1 Cleavage patterns computationally determined of the fermented milk peptide profile. Three amino acids upstream (P1, P2, and P3) and two downstream (P1' and P2') of the N and C -terminal cleavage sites are used.

\begin{tabular}{clllll}
\hline \multirow{2}{*}{ Ranking $^{*}$} & \multicolumn{5}{c}{ Cleavage specificity } \\
\cline { 2 - 6 } & P3 & P2 & P1 & P1' & P2' \\
\hline 1 & Not H, K, & Not P & Not R & F, L, W, & Not P \\
& R & & & Y & \\
2 & & & F, L or Y & Not P & \\
3 & & & K or R & \\
\end{tabular}

${ }^{1}$ Based on odds ratio by EnzymePredictor.

H: Histidine, K: Lysine, R: Arginine, P: Proline, F: Phenylalanine, L: Leucine, W: Tryptophan, Y: Tyrosine. 
Table 2. Peptides identified in fermented milks after in vitro digestion plus dialysis. Prediction for antihypertensive using the AHTpin platform. Support vector machine (SVM) score (threshold=0.9).

\begin{tabular}{|c|c|c|c|c|c|c|}
\hline Protein & Fragment & Peptide sequence & Hydropathicity & Charge & $\begin{array}{l}\text { SVM } \\
\text { Score }\end{array}$ & Prediction \\
\hline \multirow{14}{*}{$\alpha_{s 1-c a s e i n}$} & $24-31$ & VVAPFPEV & 1.31 & -1 & 1.74 & AHT \\
\hline & $24-32$ & VVAPFPEVF & 1.48 & -1 & 1.80 & AHT \\
\hline & $32-39$ & FRKENINE & -1.89 & 0 & 0.01 & Non-AHT \\
\hline & $56-41$ & DAKQMK & -1.85 & 1 & 0.09 & Non-AHT \\
\hline & $77-82$ & EQKYIQ & -1.87 & 0 & -0.65 & Non-AHT \\
\hline & $110-114$ & EIVPK & -0.06 & 0 & 0.87 & Non-AHT \\
\hline & $142-149$ & LAYFYPQL & 0.56 & 0 & 1.68 & AHT \\
\hline & $143-149$ & AYFYPQL & 0.10 & 0 & 1.63 & AHT \\
\hline & $144-149$ & YFYPQL & -0.18 & 0 & 1.11 & AHT \\
\hline & $148-164$ & YQLDAYPSGAW & -0.54 & -1 & 1.92 & AHT \\
\hline & $150-154$ & FRQFY & -0.74 & 1 & 0.29 & Non-AHT \\
\hline & $151-164$ & DAYPSGAW & -0.61 & -1 & 1.70 & AHT \\
\hline & $165-172$ & YYLPLGTQ & -0.15 & 0 & -0.05 & Non-AHT \\
\hline & $173-179$ & YTDAPSF & -0.47 & -1 & 1.00 & AHT \\
\hline \multirow[t]{10}{*}{$\alpha_{\mathrm{s} 2}$-casein } & $20-25$ & IYKQEK & -1.93 & 1 & -1.06 & Non-AHT \\
\hline & $26-32$ & NMAIHPR & -0.66 & 1 & 1.13 & AHT \\
\hline & $90-96$ & YQKFPQY & -1.76 & 1 & 1.00 & AHT \\
\hline & $97-107$ & LQYPYQGPIVL & 0.28 & 0 & 1.35 & AHT \\
\hline & $165-170$ & LKKISQ & -0.63 & 2 & -0.14 & Non-AHT \\
\hline & $165-171$ & LKKISQY & -0.73 & 2 & -0.47 & Non-AHT \\
\hline & $181-189$ & LKTVDQHQK & -1.58 & 1 & -0.79 & Non-AHT \\
\hline & $183-189$ & TVDQHQK & -2.01 & 0 & -0.49 & Non-AHT \\
\hline & $184-189$ & VDQHQK & -2.23 & 0 & 0.65 & Non-AHT \\
\hline & $190-198$ & AMKPWTQPK & -1.38 & 2 & 0.39 & Non-AHT \\
\hline \multirow[t]{11}{*}{$\beta$-casein } & $1-6$ & REQEEL & -2.45 & -2 & 1.00 & AHT \\
\hline & $81-89$ & PVVVPPFLQ & 1.21 & 0 & 1.92 & AHT \\
\hline & $90-97$ & PEIMGVPK & -0.05 & 0 & 1.85 & AHT \\
\hline & $98-107$ & VKETMVPKHK & -1.04 & 2 & 0.89 & Non-AHT \\
\hline & $100-105$ & ETMVPK & -0.6 & 0 & 0.11 & Non-AHT \\
\hline & $157-163$ & FPPQSVL & 0.47 & 0 & 2.07 & AHT \\
\hline & $182-187$ & DMPIQA & -0.07 & -1 & 0.35 & Non-AHT \\
\hline & $188-205$ & LLYQEPVLGPVRGPFPIL & 0.61 & 0 & 1.38 & AHT \\
\hline & $189-205$ & LYQEPVLGPVRGPFPIL & 0.42 & 0 & 1.63 & AHT \\
\hline & $190-196$ & LYQEPVL & 0.27 & -1 & 1.04 & AHT \\
\hline & $190-205$ & YQEPVLGPVRGPFPIL & 0.21 & 0 & 1.91 & AHT \\
\hline \multirow[t]{4}{*}{ k-casein } & $18-24$ & FDDKIAK & -0.81 & 0 & 1.31 & AHT \\
\hline & $42-48$ & YYQQRPV & -1.64 & 1 & 1.15 & AHT \\
\hline & $69-75$ & SPAQTLQ & -0.64 & 0 & -0.16 & Non-AHT \\
\hline & $96-104$ & ARHPHPHLS & -1.39 & 1 & 0.75 & Non-AHT \\
\hline \multirow[t]{2}{*}{$\beta-\lg$} & $32-41$ & DAQSAPLRV & -0.26 & 0 & 0.34 & Non-AHT \\
\hline & $51-57$ & EGNLEIL & 0.17 & -2 & -0.18 & Non-AHT \\
\hline
\end{tabular}

$\beta-\lg : \beta$-lactoglobulin 
Table 3. Peptides with reported biological activity in the dialyzable fraction of fermented goat milks with classical starter (St), classical starter plus Lactobacillus plantarum $\mathrm{C} 4(\mathrm{St}+\mathrm{LP})$ or both.

\begin{tabular}{|c|c|c|c|c|}
\hline Protein & Fragment & Sequence & Activity & Reference \\
\hline \multicolumn{5}{|c|}{ St and $S t+L P$} \\
\hline$\alpha_{s 1}$-casein & $151-164$ & DAYPSGAW & ACE Inhibitor & [33] \\
\hline$\alpha_{\mathrm{s} 1}$-casein & $144-149$ & YFYPQL & Antioxidative & [43] \\
\hline$\alpha_{\mathrm{s} 2}$-casein & $90-96$ & YQKFPQY & Antihipertensive & [38] \\
\hline$\alpha_{\mathrm{s} 2}$-casein & $165-170$ & LKKISQ & $\begin{array}{l}\text { Antibacterial } \\
\text { ACE Inhibitor }\end{array}$ & $\begin{array}{l}{[44]} \\
{[45]}\end{array}$ \\
\hline$\beta$-casein & $81-89$ & PVVVPPFLQ & $\begin{array}{c}\text { ACE Inhibitor } \\
\text { (TPVVVPPFLQP } \\
\text { ) }\end{array}$ & [27] \\
\hline $\mathrm{k}$-casein & $96-104$ & ARHPHPHLS & Antioxidative & [46] \\
\hline$\beta-\lg$ & $33-41$ & DAQSAPLRV & $\begin{array}{c}\text { ACE Inhibitor } \\
\text { (DAQSAPLRVY) }\end{array}$ & {$[35]$} \\
\hline \multicolumn{5}{|l|}{$\mathbf{S t}$} \\
\hline k-casein & $96-105$ & ARHPHPHLSF & $\begin{array}{c}\text { Antioxidative } \\
\text { (ARHPHPHLSF } \\
\text { M) }\end{array}$ & [46] \\
\hline \multicolumn{5}{|l|}{$\mathbf{S t}+\mathbf{L P}$} \\
\hline$\beta$-casein & $108-113$ & ЕМРFРК & ACE Inhibitor & [33] \\
\hline $\mathrm{k}$-casein & $25-30$ & YIPIQY & $\begin{array}{l}\text { ACE Inhibitor } \\
\text { Antioxidative }\end{array}$ & $\begin{array}{l}{[47]} \\
{[48]}\end{array}$ \\
\hline k-casein & $51-60$ & INNQFLPYPY & DPP-IV inhibitor & [12] \\
\hline
\end{tabular}

$\beta-\lg : \beta$-lactoglobulin 


\section{References}

1. Chaves-López C, Serio A, Paparella A, Martuscelli M, Corsetti A, Tofalo R et al. Impact of microbial cultures on proteolysis and release of bioactive peptides in fermented milk. Food Microbiol. 2014;42(Supplement C):117-21. doi:https://doi.org/10.1016/j.fm.2014.03.005.

2. Liu M, Bayjanov JR, Renckens B, Nauta A, Siezen RJ. The proteolytic system of lactic acid bacteria revisited: a genomic comparison. BMC Genomics. 2010;11(1):36. doi:10.1186/1471-2164-11-36.

3. Martinez-Maqueda D, Miralles B, Recio I, Hernandez-Ledesma B. Antihypertensive peptides from food proteins: a review. Food \& Function. 2012;3(4):350-61.

4. Gobbetti M, Stepaniak L, De Angelis M, Corsetti A, Di Cagno R. Latent bioactive peptides in milk proteins: Proteolytic activation and significance in dairy processing. Crit. Rev. Food Sci. Nutr. 2002;42(3):223-39. doi:10.1080/10408690290825538.

5. Minervini F, Bilancia MT, Siragusa S, Gobbetti M, Caponio F. Fermented goats milk produced with selected multiple starters as a potentially functional food. Food Microbiol. 2009;26(6):559-64. doi:https://doi.org/10.1016/j.fm.2009.03.008.

6. Quirós A, Hernández-Ledesma B, Ramos M, Amigo L, Recio I. Angiotensin-converting enzyme inhibitory activity of peptides derived from caprine Kefir. J. Dairy Sci. 2005;88(10):3480-7. doi:http://dx.doi.org/10.3168/jds.S0022-0302(05)73032-0.

7. Simsek S, Sánchez-Rivera L, El SN, Karakaya S, Recio I. Characterisation of in vitro gastrointestinal digests from low fat caprine kefir enriched with inulin. Int. Dairy J. 2017;75(Supplement C):68-74. doi:https://doi.org/10.1016/j.idairyj.2017.07.004.

8. Bergillos-Meca T, Costabile A, Walton G, Moreno-Montoro M, Ruiz-Bravo A, Ruiz-López MD. In vitro evaluation of the fermentation properties and potential probiotic activity of Lactobacillus plantarum $\mathrm{C} 4$ in batch culture systems. LWT-Food Sci.Technol. 2015;60(1):420-6. doi:https://doi.org/10.1016/j.lwt.2014.08.006.

9. Moreno-Montoro M, Olalla-Herrera M, Rufian-Henares JA, Martinez RG, Miralles B, Bergillos T et al. Antioxidant, ACE-inhibitory and antimicrobial activity of fermented goat milk: activity and physicochemical property relationship of the peptide components. Food \& Function. 2017;8(8):2783-91. doi:10.1039/c7fo00666g.

10. Tomotake H, Okuyama R, Katagiri M, Fuzita M, Yamato M, Ota F. Comparison between Holstein cow's milk and Japanese-Saanen goat's milk in fatty acid composition, lipid digestibility and protein profile. Biosci. Biotech. Bioch. 2006;70(11):2771-4. doi:10.1271/bbb.60267.

11. Ibrahim HR, Ahmed AS, Miyata T. Novel angiotensin-converting enzyme inhibitory peptides from caseins and whey proteins of goat milk. J. Adv. Res. 2017;8(1):63-71. doi:https://doi.org/10.1016/j.jare.2016.12.002.

12. Tagliazucchi D, Shamsia S, Helal A, Conte A. Angiotensin-converting enzyme inhibitory peptides from goats' milk released by in vitro gastro-intestinal digestion. Int. Dairy J. 2017;71(Supplement C):6-16. doi:https://doi.org/10.1016/j.idairyj.2017.03.001.

13. Zhang Y, Chen R, Ma H, Chen S. Isolation and identification of dipeptidyl peptidase IVinhibitory peptides from trypsin/chymotrypsin-treated goat milk casein hydrolysates by 2DTLC and LC-MS/MS. J. Agric. Food Chem. 2015;63(40):8819-28. doi:10.1021/acs.jafc.5b03062.

14. Almaas H, Eriksen E, Sekse C, Comi I, Flengsrud R, Holm H et al. Antibacterial peptides derived from caprine whey proteins, by digestion with human gastrointestinal juice. Brit. J. Nutr. 2011;106(6):896-905. doi:Doi: 10.1017/s0007114511001085.

15. Ahmed AS, El-Bassiony T, Elmalt LM, Ibrahim HR. Identification of potent antioxidant bioactive peptides from goat milk proteins. Food Res. Int. 2015;74(Supplement C):80-8. doi:https://doi.org/10.1016/j.foodres.2015.04.032.

16. Sánchez-Rivera L, Diezhandino I, Gómez-Ruiz JÁ, Fresno JM, Miralles B, Recio I. Peptidomic study of Spanish blue cheese (Valdeón) and changes after simulated gastrointestinal digestion. Electrophoresis. 2014;35(11):1627-36. doi:10.1002/elps.201300510. 
17. Farvin KHS, Baron CP, Nielsen NS, Otte J, Jacobsen C. Antioxidant activity of yoghurt peptides: Part 2: Characterisation of peptide fractions. Food Chem. 2010;123(4):1090-7. doi:https://doi.org/10.1016/j.foodchem.2010.05.029.

18. Bergillos-Meca T, Cabrera-Vique C, Artacho R, Moreno-Montoro M, Navarro-Alarcón M, Olalla $\mathrm{M}$ et al. Does Lactobacillus plantarum or ultrafiltration process improve $\mathrm{Ca}, \mathrm{Mg}, \mathrm{Zn}$ and P bioavailability from fermented goats'milk? Food Chem. 2015;187(Supplement C):314-21. doi:https://doi.org/10.1016/j.foodchem.2015.04.051.

19. Vijayakumar V, Guerrero AN, Davey N, Lebrilla CB, Shields DC, Khaldi N. EnzymePredictor: A tool for predicting and visualizing enzymatic cleavages of digested proteins. J. Proteome Res.. 2012;11(12):6056-65. doi:10.1021/pr300721f.

20. Minkiewicz P, Dziuba J, Iwaniak A, Dziuba M, Darewicz M. BIOPEP Database and Other Programs for Processing Bioactive Peptide Sequences. J. AOAC Int. 2008;91(4):965-80.

21. Kumar R, Chaudhary K, Singh Chauhan J, Nagpal G, Kumar R, Sharma M et al. An in silico platform for predicting, screening and designing of antihypertensive peptides. Scientific Reports. 2015;5:12512.

22. Tamime AY, Wszolek M, Bozanic R, Özer B. Popular ovine and caprine fermented milks. Small Ruminant Res. 2011;101(1):2-16. doi:https://doi.org/10.1016/j.smallrumres.2011.09.021.

23. Miclo L, Roux É, Genay M, Brusseaux É, Poirson C, Jameh N et al. Variability of hydrolysis of $\beta-, \alpha_{\mathrm{s} 1^{-}}$, and $\alpha_{\mathrm{s} 2}$-Caseins by 10 strains of Streptococcus thermophilus and resulting bioactive peptides. J. Agric. Food Chem. 2012;60(2):554-65. doi:10.1021/jf202176d.

24. Kumosinski TF, Brown EM, Farrell HM, Jr. Three-dimensional molecular modeling of bovine caseins: $\alpha_{\mathrm{s} 1-c a s e i n .} \quad$ J. Dairy Sci. 1991;74(9):2889-95. doi:10.3168/jds.S00220302(91)78470-1.

25. Fantuz F, Polidori F, Cheli F, Baldi A. Plasminogen activation system in goat milk and its relation with composition and coagulation properties. J. Dairy Sci. 2001;84(8):1786-90. doi:10.3168/jds.S0022-0302(01)74616-4.

26. Miguel M, Gómez-Ruiz J A, Recio I, Aleixandre A. Changes in arterial blood pressure after single oral administration of milk-casein-derived peptides in spontaneously hypertensive rats. Mol. Nutr. \& Food Res. 2010;54(10):1422-7. doi:10.1002/mnfr.200900448.

27. Abubakar A, Saito T, Kitazawa H, Kawai Y, Itoh T. Structural analysis of new antihypertensive peptides derived from cheese whey protein by proteinase $\mathrm{K}$ digestion. J. Dairy Sci. 1998;81(12):3131-8. doi:10.3168/jds.S0022-0302(98)75878-3.

28. Maeno M, Yamamoto N, Takano T. Identification of an antihypertensive peptide from casein hydrolysate produced by a proteinase from Lactobacillus helveticus CP790. J. Dairy Sci. 1996;79(8):1316-21. doi:http://dx.doi.org/10.3168/jds.S0022-0302(96)76487-1.

29. Quirós A, Ramos M, Muguerza B, Delgado MA, Miguel M, Aleixandre A et al. Identification of novel antihypertensive peptides in milk fermented with Enterococcus faecalis. Int. Dairy J. 2007;17(1):33-41. doi:http://dx.doi.org/10.1016/j.idairyj.2005.12.011.

30. Birkemo GA, O'Sullivan O, Ross RP, Hill C. Antimicrobial activity of two peptides casecidin 15 and 17, found naturally in bovine colostrum. J. Appl. Microbiol. 2009;106(1):233-40. doi:10.1111/j.1365-2672.2008.03996.x.

31. Eisele T, Stressler T, Kranz B, Fischer L. Bioactive peptides generated in an enzyme membrane reactor using Bacillus lentus alkaline peptidase. Eur. Food Res. Technol. 2013;236(3):483-90. doi:10.1007/s00217-012-1894-5.

32. Kyte J, Doolittle RF. A simple method for displaying the hydropathic character of a protein. J. Mol. Biol. 1982;157(1):105-32. doi:http://dx.doi.org/10.1016/0022-2836(82)90515-0.

33. Pihlanto-Leppälä A, Rokka T, Korhonen H. Angiotensin I converting enzyme inhibitory peptides derived from bovine milk proteins. Int. Dairy J. 1998;8(4):325-31.

34. López-Expósito I, Gómez-Ruiz JA, Amigo L, Recio I. Identification of antibacterial peptides from ovine $\alpha_{\mathrm{s} 2}$-casein. Int. Dairy J. 2006;16(9):1072-80. doi:https://doi.org/10.1016/j.idairyj.2005.10.006.

35. Tavares T, Contreras MdM, Amorim M, Pintado M, Recio I, Malcata FX. Novel whey-derived peptides with inhibitory effect against angiotensin-converting enzyme: In vitro effect and 
stability to gastrointestinal enzymes. Peptides. 2011;32(5):1013-9. doi:http://dx.doi.org/10.1016/j.peptides.2011.02.005.

36. López-Fandiño R, Otte J, van Camp J. Physiological, chemical and technological aspects of milk-protein-derived peptides with antihypertensive and ACE-inhibitory activity. Int. Dairy J. 2006;16(11):1277-93. doi:http://dx.doi.org/10.1016/j.idairyj.2006.06.004.

37. FitzGerald RJ, Murray BA, Walsh DJ. Hypotensive Peptides from Milk Proteins. J. Nutr. 2004;134(4):980S-8S.

38. Contreras MdM, Carrón R, Montero MJ, Ramos M, Recio I. Novel casein-derived peptides with antihypertensive activity. Int. Dairy J. 2009;19(10):566-73.

39. Haque E, Chand R, Kapila S. Biofunctional properties of bioactive peptides of milk origin. Food Rev. Int. 2008;25(1):28-43. doi:10.1080/87559120802458198.

40. Ortiz-Chao P, Gómez-Ruiz JA, Rastall RA, Mills D, Cramer R, Pihlanto A et al. Production of novel ACE inhibitory peptides from $\beta$-lactoglobulin using Protease N Amano. Int. Dairy J. 2009;19(2):69-76. doi:http://dx.doi.org/10.1016/j.idairyj.2008.07.011.

41. Aloglu HS, Öner Z. Determination of antioxidant activity of bioactive peptide fractions obtained from yogurt. J. Dairy Sci. 2011;94(11):5305-14. doi:https://doi.org/10.3168/jds.2011-4285.

42. Demers-Mathieu V, Gauthier SF, Britten M, Fliss I, Robitaille G, Jean J. Antibacterial activity of peptides extracted from tryptic hydrolyzate of whey protein by nanofiltration. Int. Dairy J. 2013;28(2):94-101. doi:https://doi.org/10.1016/j.idairyj.2012.09.003.

43. Suetsuna $\mathrm{K}$, Ukeda $\mathrm{H}$, Ochi $\mathrm{H}$. Isolation and characterization of free radical scavenging activities peptides derived from casein. J. Nutr. Biochem. 2000;11(3):128-31.

44. Lopez Exposito I, Minervini F, Amigo L, Recio I. Identification of antibacterial peptides from bovine kappa-casein. J. Food Protect. 2006;69(12):2992-7.

45. Lopez-Exposito I, Quiros A, Amigo L, Recio I, López Expósito I, Quirós A. Casein hydrolysates as a source of antimicrobial, antioxidant andantihypertensive peptides. Lait. 2007;87(4-5):241-9.

46. Korhonen H, Pihlanto A. Technological options for the production of health-promoting proteins and peptides derived from milk and colostrum. Curr. Pharm. Design. 2007;13(8):829-43. doi:http://dx.doi.org/10.2174/138161207780363112.

47. Gómez-Ruiz JA, Ramos M, Recio I. Identification of novel angiotensin-converting enzymeinhibitory peptides from ovine milk proteins by CE-MS and chromatographic techniques. Electrophoresis. 2007;28(22):4202-11. doi:10.1002/elps.200700324.

48. De Gobba C, Tompa G, Otte J. Bioactive peptides from caseins released by cold active proteolytic enzymes from Arsukibacterium ikkense. Food Chem. 2014;165:205-15. doi:https://doi.org/10.1016/j.foodchem.2014.05.082. 